\title{
Compatriot partiality and cosmopolitan justice: Can we justify compatriot partiality within the cosmopolitan framework?
}

\author{
Rachelle Bascara \\ Department of Politics and the Department of Philosophy, Birkbeck College, \\ University of London, r.bascara@bbk.ac.uk
}

DOI: http://dx.doi.org/10.5324/eip.v10i2.1921

(cc) BY

This is an open access article distributed under the terms of the Creative Commons Attribution 4.0 International License, which permits unrestricted use, distribution, and reproduction in any medium, provided the original author and source are credited.

This paper shows an alternative way in which compatriot partiality could be justified within the framework of global distributive justice. Philosophers who argue that compatriot partiality is similar to racial partiality capture something correct about compatriot partiality. However, the analogy should not lead us to comprehensively reject compatriot partiality. We can justify compatriot partiality on the same grounds that liberation movements and affirmative action have been justified. Hence, given cosmopolitan demands of justice, special consideration for the economic well-being of your nation as a whole is justified if and only if the country it identifies is an oppressed developing nation in an unjust global order.

This justification is incomplete. We also need to say why Person A, qua national of Country $A$, is justified in helping her compatriots in Country A over similarly or slightly more oppressed non-compatriots in Country B. I argue that Person A's partiality towards her compatriots admits further vindication because it is part of an oppressed group's project of self-emancipation, which is preferable to paternalistic emancipation.

Finally, I identify three benefits in my justification for compatriot partiality. First, I do not offer a blanket justification for all forms of compatriot partiality. Partiality between members of oppressed groups is only a temporary effective measure designed to level an unlevel playing field. Second, because history attests that sovereign republics could arise as a collective response to colonial oppression, justifying compatriot partiality on the grounds that I have identified is conducive to the development of sovereignty and even democracy in poor countries, thereby avoiding problems of infringement that many humanitarian poverty alleviation efforts encounter. Finally, my justification for compatriot partiality complies with the implicit cosmopolitan commitment to the realizability of global justice theories.

Keywords: global justice, cosmopolitanism, compatriot partiality, nationalism, democracy 


\section{Introduction}

The partiality that I will be discussing involves having a special concern for, or a disposition to favour, a particular group. In this article, I will defend the permissibility of a particular kind of partiality, namely, partiality towards the economic well-being of one's compatriots over foreigners, within the framework of global justice. My approach is consistent with the framework of global justice, because I do not argue for the absolute prioritization of one's compatriots. I only claim that partiality towards compatriots is justified if and only if one's compatriots belong to a nation that has a significant portion of its population living below the poverty line. In other words, when one is a member of a so-called developing nation, then she can be justified in being partial towards the economic well-being of the constituents of her nation taken as whole.

Let me now state the scope and assumptions of my paper. First, I assume throughout that the existing global order creates an unjust disadvantage for poor countries, taken as wholes or discrete units. I am presupposing a Thomas Pogge-type theory of global distributive justice, which holds that the arrangement of global economic institutions is unjust, because it creates severe poverty in some countries and great wealth in others. For Pogge, an institutional order is unjust if it causes foreseeable and avoidable suffering (Pogge 2008: 25). It is crucial in this conception of justice that the foreseeable suffering is unnecessary and avoidable. Roughly half of the world's current population subsists below the \$2 PPP (purchasing power parity) per day poverty line. Since we now have the means to bring everyone up to a minimum standard of living due to our technological advances in food production and resource distribution, then this order is unjust. As Pogge points out:

fifty years ago, the eradication of severe poverty worldwide would have required a major shift in the global income distribution, imposing substantial opportunity costs upon the advanced industrialized countries. Today, the required shift would be small, and the opportunity cost for the developed countries barely noticeable (Pogge 2008, 98).

In this account, demands of justice can only be substantiated when an alternative is possible. We cannot complain of injustice when people die at 100 or older. We have not developed the technology to prolong life, so we cannot say that to die at the age of one hundred, however sad that may be, is an instance of injustice. Contrast this with the 1.5 million annual diarrhoea death toll of children under five in developing countries. Diarrhoea is an easily treatable disease, and it is an injustice that this disease claims so many lives. There is an available and feasible institutional design of the global order wherein diarrhoea does not claim an exorbitant amount of lives. More generally, there is an alternative way of designing our global institutional order wherein the majority of the world's population is not trapped in a vicious cycle of severe poverty.

The view that we have an unjust global order is not unique to Pogge. For example, Immanuel Wallerstein's World Systems Theory holds that the "world system", or the world taken in its entirety, and not individual states, should be the primary focus of analysis (Wallerstein 2004: 12). Influenced by Marxist theory, Wallerstein argues that we can replicate the Marxist division of labour on a global scale, where core countries are like the powerful capitalist class, the semi-periphery countries are like the petty bourgeoisie, and periphery countries are like the oppressed and exploited proletariat. In agreement with Wallerstein, some Marxists 
argue that the main purpose of globalization is the establishment of a global capitalist order, with an accelerated polarization of wealth between rich and poor countries. In this capitalist global order, developed countries institutionally subjugate poor countries.

If Wallerstein's World Systems Theory could be construed as a reconstruction of Marxist theory on a global scale, Richard Arneson's prioritarianism could be construed as a form of global consequentialism. My account of compatriot partiality is, more specifically, a response to Arneson's objection to the idea that we can be justifiably partial towards the economic well-being of our compatriots by virtue of their standing as our compatriots (Arneson 2004: 23). Despite their divergent philosophical starting points (Pogge is a Rawlsian liberal, and Arneson is a consequentialist) the heart of Arneson's thesis is in line with Pogge's. But given Arneson's global prioritarian framework, I intend to show how or why we can prioritize the economic well-being of compatriots over similarly needy-though not significantly needier-foreigners.

It is important to stress that since prioritarianism is a variety of consequentialism, its application would likely permit prioritizing the economic needs of compatriots for instrumental reasons. As the avowed cosmopolitan Martha Nussbaum pointed out, if everyone focused on the well-being of the people around them, then we would be more efficient in achieving the aims of justice. Instead of dividing our attention equally among all the children in the world, we should focus our attention on our own children, not because they are more morally worthy of our attention, but because this is the best way in which we can benefit humanity as a whole (Nussbaum 1996: 13). However-and this is where I disagree with Arneson-I am not justifying compatriot partiality on purely instrumental reasons. My account permits compatriot partiality even when one can have more impact in another poor country.

A further issue that I need to address is that, given that I am framing the problem in terms of global justice, one could argue that the compatriot partiality I am defending is not an instance of partiality at all. As Ronald Dworkin once highlighted, treating people as having equal value does not automatically translate into treating them uniformly or in the same manner (Dworkin 1981: 244). Sometimes, treating people as equals requires us to treat people differently. People have different needs, and equal treatment may only exacerbate existing inequalities. In the context of individuals, for example, we need to take into account that people have different mobility needs. In order to ensure that we are taking everyone's interests equally into consideration, we ought to have wheelchair accessible spaces and transportation. In the international setting, if Citizens of Country $\mathrm{X}$ are harmed by practice or institutional order $\mathrm{Y}$, then everyone has a duty to stop the practice and remedy institutional order $\mathrm{Y}$, as well as compensate for the harms already done. Everyone would have a duty to depart from uniform treatment in order to redress legitimate grievances and to compensate for past harms. This makes it a case of impartiality rather than partiality, for the duty to remedy the injustice falls on all relevant actors, regardless of national membership. An upshot of Arneson's account is that everyone has the obligation to improve the situation of the worst-off members of the global order. If we were to think about global prioritarianism's practical application, bearing in mind that it is a consequentialist theory, since Sub-Saharan Africa is the poorest region in the world, everyone, including people in South Asia (the second poorest region), is obligated to work in 
poverty alleviation in Sub-Saharan Africa, unless they can prove that they can have more impact in their own region.

On the question of whether this is indeed a case of partiality, I shall show that, at least at the level of the person who prioritizes the economic well-being of her compatriots, it really is a case of partiality, because she is being partial to the economic well-being of the members of her own country. The justification I offer is designed to offset the duty one has to the global poor in general, when one is a national of a developing country. To illustrate, take two cases of oppressed groups, Group A and Group B. Say Group A is more oppressed than Group B. From Arneson's perspective, Person B is required to work on emancipating Group A by virtue of the fact that Group A is more oppressed. The value of improving the condition of Group A is greater than the value of improving the condition of Group B. Impartiality demands that Person B works on emancipating Group A on a global prioritarian's account. In my account, Person B will be justified if she works on emancipating Group B, even if she could have more emancipatory impact if she works with Group A. This makes it a case of partiality because she is favouring the interests of her own group, despite the existence of a more oppressed group.

Additionally, I also call the alleviation of global poverty a case of partiality to accommodate dissenters to the very notion of global justice. People who reject that assessments of justice can be made on a global level can still find value in my account. Some philosophers, like Thomas Nagel, deny the possibility of global justice in the absence of global governance (Nagel 2010: 2). According to Nagel, the claim that severe global poverty is an issue of justice is contentious and possibly "chimerical". Nevertheless, he claims that the global poor can impose duties of aid on others on humanitarian grounds. My justification for compatriot partiality can be applicable to those who deny that there are justice-based duties to the global poor but nevertheless accept that something-whatever that something is-should be done about severe global poverty. This is a further reason why I use the term "partiality", despite my agreement with the (impartial cosmopolitan moral) demand that we must equally assess everyone's needs globally. To recapitulate, the compatriot partiality I am defending is a case of partiality because, first, it permits the prioritization of one's co-members in an oppressed group despite the existence of more oppressed groups and, second, to appeal to global justice dissenters.

In order to appreciate the aim of this paper, I must emphasize the global context in which I am defending such compatriot partiality. I am not assuming that each and every token member (or citizen) of a developing nation is oppressed by the unjust global order. Like the level and focus of analysis propounded in World Systems Theory, I take a macro-level global perspective, where the viewing of a developing nation as a discrete unit oppressed by the global order does not imply that each and every citizen of that developing nation is necessarily oppressed. Descriptive ascriptions to collective entities, like nations, do not automatically distribute to its individual constituents. Nations are a type of institution. If, as Pogge points out, responsibility for the repair of unjust institutions falls, first and foremost, on those who uphold the institutional order, then, in the local setting and as Pogge himself argues, the leaders and the elite of developing nations are charged with significant responsibility for their imposition of an unjust local institutional arrangement, which causes severe poverty for their compatriots (Pogge 2008: 72).

Finally, I should admit that my account leaves open the question of who one's compatriots are. Roughly speaking, compatriots are our co-participants in a coercive 
local government or state who share a history and current state of oppression. This formulation is not uncontroversial. Thus, I am abstaining from committing myself to a particular conception of who counts as a compatriot, since this is a distinct and controversial matter altogether.

\section{The Structure of Compatriot Partiality}

From an impartial moral perspective, the value of saving one drowning person over another drowning person is the same. But if I see two drowning people, where one is my brother, if I can only save one, then I have an additional reason to save my brother (Williams 1981: 18). I stand in a special relationship with this person by virtue of his being my brother. In common sense morality, partiality towards one's family members is often not only considered to be justified but also seen as a duty. We say that our bias towards the well-being of our family or loved ones is justified because we stand in a special relationship to them that generates special obligations and warrants partiality.

Given the legitimacy of familial partiality in common sense morality, it is unsurprising that philosophers have attempted to justify compatriot partiality by drawing an analogy between familial partiality and compatriot partiality. Thomas Hurka presents a justification of partiality towards compatriots via an analogy to his love for his wife (Hurka 1997). The justification for his spousal love is twofold: (1) the correctly identified objectively good qualities that she has; and (2) the shared history of objective good that they have together. Hurka claims to love his wife because she is kind, intelligent, and trustworthy. But even if these were correctly identified objectively good qualities, they would be insufficient to justify his partiality towards her. If he loved his wife solely on these grounds, someone who had the same qualities could acquire similar claims on him. It would mean that his wife would be replaceable by anyone who has these qualities. Hence, Hurka's first reason has to be complemented by another reason in order to count as a justification. It is an important aspect of Hurka's love that his wife is the person with whom he has had various life experiences, where they were engaged in a symbiotic history. Throughout their time together, they produced benefits for each other, suffered hardships together, and have significantly shaped each other's lives. It is because both conditions are met that his partiality towards his wife is justified.

Hurka argues that compatriot partiality can be similarly justified. First, we must identify objectively good qualities of our compatriots. In my case, Filipinos are thought of as resilient and hardworking. Assuming that these qualities are good, and that I am correct in my attribution, then my partiality towards my compatriots is partly justified. The second part of the justification requires a shared history of objective good. In my lifetime, the Filipino people have ousted two corrupt presidents through peaceful civil disobedience known as the People Power Revolution. We gathered in the hundreds of thousands and refused to return to school or work until the president resigned from his position.

Having met Hurka's two conditions, let us now examine how this works in the drowning scenario, where the fact of one of them being my brother is an additional reason to save that person. Firstly, let me point out that Hurka's account does not justify familial partiality per se. If he is right, then it will justify instances of partiality where the two conditions are met, and many familial relations, by virtue of the nature of typical familial relations, are able to satisfy the criteria. Many 
compatriot relations are unable to meet these criteria simply because we do not normally have direct interaction, or have a personal relationship, with our compatriots qua compatriots, and these are typically the background requirements for being able to satisfy Hurka's two conditions. Personal relationship or direct interaction is what enables the identification of good traits and sharing a history of objective good.

But I also contend that Hurka's justification does not work for compatriot partiality, because familial and compatriot partiality are fundamentally different kinds of partiality. Even if we can satisfy Hurka's two requirements of how we must identify objectively good qualities of our compatriots and how we shared a history of objective good with them, these cannot be reasons for why we would be justified in choosing to save that particular person. The situation of the drowning people, we can stipulate, is a freak accident. The responsibility to save them does not turn on anything other than the mortal threat they face. So even if I can say that Filipinos are hardworking, resilient, and that I shared a history of ousting two corrupt presidents with them, these are not relevant reasons for why I can save that drowning Filipino person. In this ethical scenario, that person's status of being my compatriot is morally arbitrary. It is morally arbitrary because one's national membership is not a morally relevant consideration for whether a person would have additional claims of aid when her life is in danger. As many cosmopolitans have pointed out, the two drowning strangers have equal claims of aid by virtue of their intrinsic equal moral worth. Thus, a fair strategy for this dilemma would be to flip a coin in order to decide which person you would save.

Moreover, even if we suppose that Hurka's justification for partiality is acceptable, there is no guarantee that this drowning Filipino person is hardworking, resilient, or that this person was in fact a supporter of the People Power (EDSA) revolutions. If, however, I know for a fact that this person is hardworking, resilient, and was a participant of the EDSA revolution, then that would not be due to my knowledge that this person is a Filipino. Perhaps I actually know this person through direct interaction, or perhaps I just know about this person. Maybe it is permissible to save someone whom you know something about over someone you know nothing about. At least intuitively, this seems possible, since I can imagine this making a phenomenological difference in our reasoning, but-for the purposes of this paper-I do not need to commit myself to an answer. The only point I want to make here is that Hurka's justification for familial partiality works in this drowning scenario but would not work for the compatriot case. ${ }^{1}$ This further corroborates my claim that familial partiality is a different kind of partiality from compatriot partiality. The partiality and fondness that we have for our family (or friends) is a particular kind of partiality, which is limited to a certain number of people. The British anthropologist Robin Dunbar found a correlation between primate brain size and social group size (Dunbar 1992: 287). He estimated that human beings can only maintain an average of 150 stable relationships. Since the number of compatriots a person has is an exponentially larger number than this, it is unlikely that we could make a convincing argument for compatriot partiality via familial or friendshipbased partiality.

To be clear, I am not claiming that in discrediting Hurka's justification for compatriot partiality, I have shown that all justifications for compatriot partiality fail. All that I am saying is that Hurka's particular justification for compatriot partiality, based on an analogy with familial partiality, fails. Paul Gomberg and 
Simon Keller seem correct in saying that if we justify the decision to save a drowning person by virtue of his status as a compatriot, it is akin to trying to justify saving someone because you belong to the same race (Gomberg 1990; Keller 2005). Critics of compatriot partiality seem correct in their argument that compatriot partiality is more like racial partiality, especially since one's compatriots or co-race represent an incredibly large number of people. In the same way that we cannot identify objectively good qualities of our compatriots or co-races that are distributable to each and every token, and because we cannot say that any particular history of objective good is in fact shared with all of our compatriots, then Hurka cannot justify compatriot partiality on these same grounds.

Philosophers who accept the analogy find it to be a decisive reason to comprehensively reject compatriot partiality. While I think that such critics are correct in identifying the structural similarity, I do not think that it necessarily precludes compatriot partiality. In the next section, we shall focus on the development of racial discrimination, which will pave the way for the justification of some compatriot partiality.

\section{Unjustified Partiality Can Justify Counter-Partiality}

The enslavement of Africans is probably among the most pronounced and reprehensible manifestations of racism. By virtue of something as morally irrelevant as skin colour, people were disqualified from having the status of human beings. Slaves could be bought, sold, raped, and killed without social, moral, or legal repercussions. Fortunately, we now look at slavery with disgust, and no one can openly endorse it, at least in most developed parts of the world, without suffering public disapprobation. It is more or less an established moral norm and institutionalized fact that slavery, and the racism and colonial mentality from which it springs, is morally abhorrent.

However, there was once a time when slavery and racism were not considered bad. It was normal practice to treat people a certain way because of their skin colour. In other words, we have been able to change our institutions, social practices, and moral outlook on racism and slavery. How did we get from slavery being a norm to the current situation? What significantly contributed to moral progress is the recognition of the unjust discrimination among the members of the oppressed group. There came a point when black people in the US acknowledged the racial bias and collectively opposed it. They recognized the racial discrimination and then defined themselves as a racially oppressed group. Throughout history, oppressed groups have learned that the best way to fight discrimination is to identify themselves as an oppressed collective and to articulate demands as a collective. Once there is a collective body that has been identified as oppressed, special attention to the well-being of its members and between co-members is justified (Jamieson 2002: 337). We generate the special attention to oppressed groups from the impartial moral perspective that requires us to take everyone's interests equally into consideration.

In other words, the identification of an oppressed group warrants special attention towards that group. For those who accept the main premises of global justice, then they can agree that we all have a duty to remedy the injustice. For those who reject the idea of global justice, then at least they can accept that the situation of the global poor generates a requirement to be particularly concerned about their 
plight. Hence, given the situation of severe global poverty, we could make a case for compatriot partiality by recognizing that certain national collectives are unjustly subjugated by our global order. If, like the oppression of black people in western slave societies, developing countries are oppressed, then special attention towards these developing countries and their members is justified.

My justification for compatriot partiality is, thus far, glaringly incomplete. All that we have established is that special consideration for oppressed groups is warranted. If, by happenstance, the oppressed group is a group of your compatriots, then so be it. But so far we have said nothing about why Person A might be justified in helping people in Country A, qua citizen of Country A, as opposed to similarly oppressed people in Country B. All forms of emancipation from unjust subjugation are good and valuable, including paternalistic emancipation. But, ceteris parebus, self-emancipation is preferable to paternalistic emancipation because the exercise of their collective agency plays an important role in their emancipation. In the case of the oppression of developing countries, this is of even greater relevance, since it is part of the self-emancipation of a national collective, which enables sovereignty and could pave the path towards democracy.

Let us again draw from the experience of another oppressed collective, namely, women. Men can be feminists, and men can and do support the feminist movement. But part of the oppression of women is that patriarchal structures institutionally subjugated them and undermined their capacities. So a special feature of the project of resisting patriarchal oppression is that it is women who demand the changes because that plays a special part in the process of their emancipation. This idea is the underlying motivation for feminist standpoint theory. According to this theory, women, by virtue of their membership in a gender-oppressed class, have a privileged epistemic position, which could and should be used for their emancipation (Brooks 2007: 55). There is something powerfully persuasive when a woman who is supposed to wear a burka condemns the practice, and yet it can be slightly disconcerting when a western woman condemns it. I would even go as far as to contend that full emancipation cannot be attained by paternalistic emancipation alone. It is only when the oppressed themselves are able to actively exercise their agency that full emancipation can be realized.

Something similar can perhaps be said of compatriot partiality. The special attention to oppressed groups is justified in itself, but the fact that you are a member of such a group admits further vindication. It converts the special consideration derived from the impartial moral perspective into partial consideration or partiality. Membership in an oppressed group comes with the epistemic privilege to speak for, and advance the interests of, an oppressed group as a member of, and not merely for, the group. This is valuable to any group's fight against oppression because it paves the path for self-emancipation. In the 2013 Climate Change Convention in Warsaw, just after the most devastating typhoon recorded in history hit the Philippines, the Philippine representative, Naderev Sano, pleaded for the urgent need for the implementation of the Green Climate Fund, a programme designed to take into account, among other things, the needs of developing countries particularly vulnerable to the adverse effects of climate change. The Green Climate Fund acknowledges and addresses the current climate situation, which can be linked to the $\mathrm{CO}_{2}$ emissions of the first nations to industrialize at the expense of those still industrializing. His speech stirred the delegates because he spoke from an epistemically privileged position. He was representing the people of a country 
considered among the most vulnerable to climate change, where a recent tragedy took place, claiming the lives of his very own loved ones. This is why Malala Yousafzai's valiant advocacy for the right to education captured international media attention, public veneration, and a Nobel Prize. There is great value when members of the oppressed group speak against their oppression, and demand justice and recompense for the harms they suffered or are suffering. If we agree with the premise that developing countries are unjustly subjugated by our global economic order, then we should also agree that partiality for one's own oppressed people is justified. This is why a Bangladeshi would be justified in working in poverty alleviation in Bangladesh, an Indian would be justified in donating her extra income to her destitute fellow Indians, even if they could make more impact in a country not their own.

There is an ongoing paternalistic defence of the interests of the global poor in the West and by westerners. Pogge's project is to change the incentives for pharmaceutical companies in order to make medicines more accessible to the poor. Leif Wenar is adamant that western nations ought to stop doing business with corrupt and tyrannical rulers from poor nations. Britain's Jubilee Debt Campaign calls for the cancellation of debts in the developing world. These are all good and valuable, and arguably even necessary. But there is special significance when pharmaceutical companies in India, citizens of resource-rich countries subjected to corrupt leaders, and representatives of developing nations who are burdened with debt resist and condemn these unjust practices, and represent their own interests in international assemblies.

Thus, to answer the earlier question: Person A can help people in Country A over similarly oppressed people in Country B because she is contributing to an oppressed group's project of self-emancipation. Such self-emancipation is preferable to paternalistic emancipation, and its value cannot be transposed onto other people who are not members of the group. This is the sense in which compatriot partiality in global distributive justice can sometimes be justified. To sum up: Compatriot partiality can be justified amidst cosmopolitan demands of justice if one is from a developing nation, because special consideration towards oppressed groups in general is warranted and because an oppressed group's project of self-emancipation is instantiated in the partial compatriot.

\section{Reaffirming Cosmopolitanism's Basic Tenet}

The justification that I offer for compatriot partiality is an upshot of the justification of partiality between co-members of oppressed groups. Given my agreement with the view that compatriot partiality is structurally similar to racial partiality, it can not be surprising that I am not endeavouring to justify compatriot partiality per se.

The goal is still to get rid of partisan loyalties and arbitrary biases. The compatriot partiality that I am justifying is only a reaction to biases and injustice and is only warranted insofar as it fulfils the function of restoring justice. We propagate the practice of affirmative action not because we think this is the right universal moral code for how we should live together, but because we look at the context that we are in and infer that it is the right thing to do. Affirmative action sometimes requires us to favourably bias or positively discriminate for minorities, given unjust and entrenched stereotypes and the history of excluding women and people of colour in education, politics, and paid employment. We recognize that if we were to start 
treating everyone equally now, it would be a moral failure because we are failing to acknowledge the unfair head start that some people have had. It would be tantamount to refusing to acknowledge the effects of historical and institutional oppression. Affirmative action in the case of women and ethnic minorities is only a temporary measure designed to level an unlevel playing field. Once we are (at least nearly) there, then there would be no need for affirmative action. The same is true for compatriot partiality. The aim is to make it unnecessary and unjustifiable because we have transcended the situation that requires it.

\section{Conclusion}

Cosmopolitans of justice have always argued that national boundaries are irrelevant to distributive justice. For instance, Pogge argues that we must not let a person's country of birth or national identity play a role in the determination of what is due to her on grounds of justice (Pogge 1989). According to him, a consistent application of Rawls's principles of justice would require a special concern for the global poor, because they are the worst-off members of the human race. The fact that they are not our compatriots is morally irrelevant because it is typical for people to have done nothing to deserve their citizenship. Just as Rawls said that the social class that you are born into, your sex, and natural talents are morally arbitrary, your country of birth cannot be grounds for excluding you from the sphere of distributive justice. This is how Pogge is able to ground his cosmopolitan imperative-by rejecting the relevance of national boundaries to the issue of one's entitlement to economic resources.

However, in saying that ordinary wealthy citizens of affluent countries are morally responsible for severe poverty, he smuggles back the relevance of national boundaries (Pogge 2008: 247). According to Pogge, affluent citizens of wealthy nations are morally responsible for severe poverty overseas because they are beneficiaries and participants in the upholding of an unjust global economic institutional order, which foreseeably causes avoidable suffering. Whilst your country of citizenship is morally irrelevant to the issue of what is due to you, your citizenship suddenly becomes relevant in determining your moral responsibility for severe poverty.

There is, however, a way in which Pogge can justify this move. Pogge points out that citizens of affluent countries are morally responsible for severe poverty because these affluent countries are democracies. Citizens of affluent countries are accountable for the actions of their leaders and governments, because democracies are structured such that their citizens could be, in principle, held accountable. As he puts it, democratic governments are "elected by us, responsive to our interests and preferences, acting in our name and in ways that benefit us" (Pogge 2008). Using this principle, the leaders of powerful countries that force unilateral trade agreements onto poor nations are the authorized representatives of democratic citizens in affluent countries. Admittedly, the current reality is that citizens of democracies are not sufficiently involved or consulted by their governments, especially when it comes to foreign and economic policies. However, even with the knowledge that, in practice, the production of such policies is never democratic enough, the thought is that, given that such nations are self-proclaimed democracies, we ought to start holding citizens accountable for the actions and policies of their leaders and 
governments. Holding citizens of democracies accountable is not a descriptive but a prescriptive assertion.

Citizens of developing nations, as Pogge and Wenar (Wenar 2008: 3) have already emphasized, do not usually have democratic governments. Moreover, when a significant portion of the population is in severe poverty, democratic and political participation becomes unfeasible. There is a sense in which the global poor's nationality is much less morally relevant than the nationalities of people from democratic governments. Citizens of democratic states could be made to acquire some degree of accountability for the actions of their leaders and institutions, whereas subjects of dictatorships do not.

The compatriot partiality that I espouse is conducive to the formation of democracy because "the identity of a people has often been formed through resistance to oppression" (Wenar 2006: 401). Just because history and the current situation at large tell us that the ideal of democracy can probably never be attained does not mean that we should not strive towards it. As Winston Churchill famously said, democracy is the worst form of government, except for all those other forms that have been tried. Compatriot partiality is a valuable instrument that could cultivate the democratic ethos of oppressed countries to level their bargaining position in the international arena. What should not escape our notice in the current literature of global justice is that there is strong instrumental reasoning in their prescriptions. The implementation of Pogge's Health Impact Fund would make life-saving medicines more accessible to poor people. Wenar's Clean Hands Trust is designed to be applicable to the existing global trade practices and beneficial to people in resource-rich countries. Peter Singer's calculations about how we could eradicate severe global poverty if every ordinary affluent westerner contributed a small portion of their wealth is supposed to convince people to actually do it (Singer 2010: 157). The cosmopolitan philosophers are not just in this discussion for the sheer pleasure of philosophical argumentation: there is a palpable concern for the realizability of their theories.

When Rawls wrote A Theory of Justice, he ignored the philosophical trend of his time about the "unspeakability" of moral and political judgements. Against the prevalent non-cognitivist trend, Rawls disregarded the conviction of his colleagues about the inapplicability of philosophy to political thought. He did not attempt to refute the logical positivists who claimed that moral and political statements are matters of taste. Instead, he simply demonstrated how we could use philosophy in thinking about politics. Cosmopolitan philosophy can be said to be doing something similar. Political philosophy is currently in a state of an extreme level of abstraction, with sanitized thought experiments and laboratory-like examination of ideas (Geuss 2008: 9). Cosmopolitan philosophy is different from other political philosophies in that it begins with such an abstract idea-the equal moral worth of persons-but ends up being useful for the advocacy of an urgent, real, moral and political concern, namely, severe global poverty. Cosmopolitan philosophers have not attempted to bridge the gap between theory and practice: they simply demonstrated how theory could be used for real-world political advocacy. This ties back into the prevalence of instrumental reasoning in cosmopolitan political philosophy. Cosmopolitans want their abstract persuasions to have an effect in the real world. There is significant instrumental reasoning within their theories because they want their accounts to have an impact on real global poverty. The instrumental thinking 
in cosmopolitan accounts of justice is a feature of the goal to apply abstract philosophical commitments to real politics.

The compatriot partiality that I am defending is amenable to the flourishing of a democracy and could provide us with a usable vehicle for the realization of cosmopolitan demands of justice. One of the problems with contemporary citizens is political apathy, and this has been lethal in poor countries. There is a deep sense of helplessness and hopelessness about the blatantly undemocratic powers that hold office in developing nations. We do not just mistrust our governments; we see them as a threat to our well-being. Hence, there is a very weak conception of the political "we" in poor countries. The institutional subjugation of poor countries in the unjust global order and the prevalence of blatantly corrupt and tyrannical rulers have consistently reinforced a pervasive and debilitating pessimism for our capacity for self-governance. However, advances in justice on the global level would have negligible effects on the global poor so long as their home countries remain blatantly unjust. Even if we achieve a just global order, there would be no hope for the eradication of severe global poverty if there is no simultaneous alteration of the local context wherein such poverty persists. The project of realizing global justice necessarily goes hand-in-hand with the project of realizing local justice.

Moreover, current efforts by international NGOs and humanitarian projects to improve the situation of the global poor have been criticized for breaching sovereignty. If we simultaneously highlight and encourage the need for people in the developing world to secure local justice and take responsibility for the severe poverty in their home countries, humanitarian and paternalistic efforts need not overstep lines of sovereignty. Instead of leading poverty-alleviating efforts, humanitarian aid agencies can simply assist the efforts of citizens in the developing world.

If we were to foster the creation of a national identity that could conceivably have a place in the governments of developing countries that would, among other things, advance their interests in international assemblies, then perhaps more people would actually care. (Woons 2014, "When identity changes are the result of historical injustices or material imbalances that hinder a nation's ability to selfdetermine, social justice might entail greater recognition to establish balance within the multinational community.") Susan James said that a sincere effort for the realizability of our political theories would have to take our passions into serious consideration (James 2003: 234). Partiality is sometimes an emotion, passion, or reactive attitude. If we are sincere about the realizability of our cosmopolitan principles of justice, then we must use the patriotic bias for the cosmopolitan imperative.

\section{Notes}

${ }^{1}$ An upshot of Hurka's justification is that if your brother is a bad person, you would not be justified in saving that person. This seems counter-intuitive, but I am not here to assess the merits of Hurka's justification for familial partiality.

\section{References}

Arneson, R. (2004). Do patriotic ties limit global justice? The Journal of Ethics, 9(1), 127-50. http://dx.doi.org/10.1007/s10892-004-3323-x 
Brooks, A. (2007). Feminist standpoint epistemology. In Feminist Research Practice: A Primer, ed. S.N. Hesse-Biber and P.L. Leavy, 53-82. Thousand Oaks: Sage Publications. http://dx.doi.org/10.4135/9781412984270.n3.

Dunbar, R. I. M. (1993). Coevolution of neocortical size, group size and language in humans. Behavioral And Brain Sciences, 16(04), 681-94. http://dx.doi.org/10.1017/S0140525X00032325

Dworkin, R. (1981). What is Equality? Part 1: Equality of Welfare. Philosophy \& Public Affairs, 10, 185-246

Geuss, R. (2008). Philosophy and Real Politics. New Jersey: Princeton University Press. http://dx.doi.org/10.1515/9781400835515

Gomberg, P. (1990). Patriotism is like racism. Ethics, 101(1), 144-50. http://dx.doi.org/10.1086/293264

Hurka, T. (1997). The justification of national partiality. In The Morality of Nationalism, eds. R. McKim and J. McMahan, 139-157. New York: Oxford University Press.

James, S. (2003). Passion and Politics. New York: Cambridge University Press. http://dx.doi.org/10.1017/cbo9780511550270.014

Jamieson, D. (2001). Is there progress in morality? Utilitas, 14(3), 318-38. http://dx.doi.org/10.1017/S0953820800003630

Keller, S. (2005). Patriotism as bad faith. Ethics, 115(3), 563-92. http://dx.doi.org/10.1086/428458

Nagel, T. (2010). The problem of global justice. In The Cosmopolitan Reader, eds. G. W. Brown and D. Held. Cambridge: Polity Press

Nussbaum, M. C., \& Cohen, J. (1996). For Love Of Country. Boston: Beacon Press.

Pogge, T. (1989). Realizing Rawls. Ithaca: Cornell University Press

Pogge, T. (2008). World Poverty and Human Rights. 2nd ed. Cambridge: Polity Press

Rawls, J. (1971). A Theory Of Justice. Cambridge, MA: Belknap Press of Harvard University Press

Singer, P. (2009). The Life You Can Save. New York: Random House

Wallerstein, I. (2004). World Systems Analysis: An Introduction. Durham: Duke University Press

Wenar, L. (2006). Reparations for the future. Journal Of Social Philosophy, 37(3), 396-405. http://dx.doi.org/10.1111/j.1467-9833.2006.00344.x

Wenar, L. (2008). Property rights and the resource curse. Philosophy \& Public Affairs, 36(1), 2-32. http://dx.doi.org/10.1111/j.1088-4963.2008.00122.x

Williams, B. (1981). Moral Luck. Cambridge: University Press. http://dx.doi.org/10.1017/CBO9781139165860 
